\title{
UNDERSTANDING THE BULHOEK MASSACRE: VOICES AFTER THE MASSACRE AND DOWN THE YEARS
}

\author{
D.H. MAKOBE \\ DOCUMENTATION SERVICE DIRECTORATE, SANDF
}

\begin{abstract}
Die gevolge van die Bulhoekopstand het uiteenlopende reaksies ontlok. Afhangend vanuit watter politieke oogpunt die aangeleentheid benader is, het die toerekening van blaam gewissel van die Israeliete sélf tot die Regering se optrede. Hierdie verskillende reaksies word ontleed.
\end{abstract}

The squatting and defiance of the law by the followers of Enoch Mgijima (Israelites) at Bulhoek was an unwelcome exercise by the people who stayed in the vicinity of Queenstown. Various African leaders, including the members of the South African Native National Congress (SANNC), tried to persuade the Israelites to leave Bulhoek peacefully. The massacre generated mixed reactions from different political organisations: within parliament, the general public and from various newspapers. There were many fiery debates about the tragedy after the massacre and the trial. ${ }^{1}$ Almost every newspaper in the country at the time carried reports about the events of 24 May 1921. The newspaper reports give a clear indication of who was blamed for the Bulhoek massacre. It is the purpose of this article to analyze what the nation at the time thought of the conflict between the Israelites and the government and what African political leaders thought of the event down the years.

\section{THE SANNC}

24 May 1921 was an important day in the Union of South Africa. It was a British public holiday, Empire Day, and it was the birthday of General Jan Smuts, who was then the Prime Minister of the Union of South Africa. It was also the day on which the Bulhoek massacre occurred. On the same day the SANNC held its ninth annual meeting since its formation in 1912 at Bloemfontein. ${ }^{2}$ The news of the events at Bulhoek stirred delegates at the

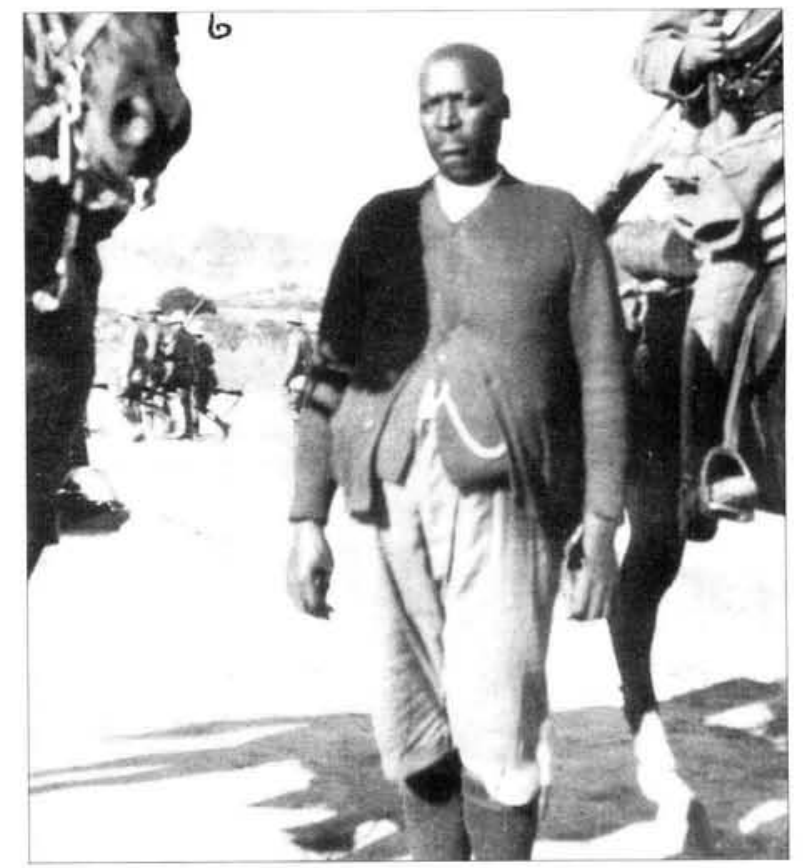

Enoch Mgijima

Africa Museum, Johannesburg

SANNC conference deeply. S.M. Makgatho, who was the chairman, requested delegates to debate on the incident. The Congress declared that the Government had failed to respect the religious convictions of the Israelites, and expressed doubts whether the authorities would have taken the same drastic measures in a similar situation if it had been created by people of European descent. ${ }^{3}$

The trial of the Israelites commenced on 21 November 1921 and concluded on 2 December 1921 in Queenstown. For a complete account of the trial see: South African Police Service Archives, Pretoria (hereafter SAPS Archives): Box 4202 Bulhoek massacre records, File 6/850/21/H Trial of Israelites, Report of paper clippings.

SAPS Archives: Box 4202, File 6/850/21 Press Cuttings, Native Congress and Bulhoek Tragedy, Rand Daily Mail, 1921-05-27. SAPS Archives: Box 4202, File 6/850/21 Press Cuttings, Native Congress and Bulhoek Tragedy, Rand Daily Mail, 1921-05-27. 
As a way of condemning the Government's actions at Bulhoek, the Congress adopted two resolutions. The first resolution declared that "...the GovernorGeneral of the Union of South Africa, as a representative of the King, is the Supreme Chief of the Bantu races and as such on all matters affecting the Bantu population should from time to time, according to the exigencies of the moment, take advice from chiefs and leaders. It was complained that the Supreme Chief was not approachable, and it was not known how he got direct advice from the natives. The native people placed their trust and protection upon the King." ${ }^{4}$ The Congress blamed the Governor-General of the Union of South Africa for not taking any steps to protect the Israelites at Bulhoek.

The second resolution called for the repeal of the Natives Land Act of 1913. They argued that the Government had failed to carry out its principles and the Act itself was impracticable. The Congress felt that the position was getting serious and that in other places something similar to the Bulhoek affair might occur. ${ }^{5}$ To the SANNC the Israelite sect had attracted people who had been pushed off their land by the 1913 Land Act. People who joined the Israelite sect, according to the SANNC, had abandoned their homes to join the sect. ${ }^{6}$

The Congress sent a telegram to Arthur Barlow, (Member of Parlaiment for Bloemfontein North) as well to request a parliamentary inquiry into the shootings. The Congress further decided to undertake the defence of those arrested at Bulhoek. As a solemn demonstration of protest, the Congress adjourned and marched in procession through the location, with the band playing the Death March, after which a service was held in memory of the dead. $^{7}$

As time went by the SANNC, which later became the African National Congress (ANC), continued to draw its own conclusions about the massacre. The national significance of the Bulhoek massacre in the struggle for liberation was expressed by the ANC leader Professor Z.K. Matthews during the Treason Trial (1956-1961) when he said that Bulhoek massacre "...is talked about to children and so on, as an incident that has passed into what we might call the political history of the people." 8 In 1962 while addressing the conference of the PanAfrican Freedom Movements of East and Central Africa (PEFMECA), Nelson Mandela referred to the massacre by saying that "South Africa is known throughout the world as a country where the most fierce forms of colour discrimination are practised, and where peaceful struggles of the African people for freedom are violently suppressed. It is a country torn from top to bottom by fierce racial strife and where the blood of African patriots frequently flow. Almost every African household in South Africa know about the massacre of our people at Bulhoek in the Queenstown district where detachments of the army and police armed with artillery, machine guns and rifles, opened fire on unarmed Africans."

Since 1921 the Bulhoek massacre has been viewed by Africans as part of the struggle for national liberation. G.V. Mqingwana, a lecturer in the history department at the University of Transkei (Butterworth branch) said this about the massacre in his thesis that "One can safely say that there developed not only a physical but also a symbolic link between Ntabelanga and later the African nationalist resistance which culminated in the Sharpeville massacre in 1960."10

In the post-1976 students uprisings, knowledge of history of the resistance to oppression before and after the imposition of apartheid became a weapon in the struggle and facts were not always viewed objectively. Facts were interpreted in such a way as to further the aims of the Mass Democratic Movement, the latter being a movement which solidified all black freedom movements in South Africa in the late 1980s. Robert Edgar produced a booklet in 1988 on the Bulhoek massacre and reinterpreted the event as an act of heroism. ${ }^{11}$ Students and workers viewed Israelites who had died at Bulhoek, as political heroes who sacrificed their lives for the struggle for national liberation. The massacre was quoted at political rallies in the townships and was categorised with other tragedies such as the Sharpeville massacre of 1960 , the Soweto riots of 1976 and the Langa massacre of 1985.

SAPS Archives: Box 4202, File 6/850/21 Press cuttings, Native Congress Resolutions, The Star, 1921-05-27; Meeting of the South African Native Congress, Rand Daily Mail, 1921-05-28.

SAPS Archives: Box 4202, File 6/850/21 Press Cuttings, Meeting of the South African Native Congress, Rand Daily Mail, 1921-0528.

For an analysis of the reasons why the followers of Enoch Mgijima decided to settle at Bulhoek see D.H. Makobe, Confrontation with the Police:The Israelites of Enoch Mgijima and the Bulhoek massacre of 24 May 1921, Militaria 26 (1), 1996, p 23.

SAPS Archives: Box 4202, File 6/850/21 Press Cuttings, The Star, 1921-05-28; Rand Daily Mail, 1921-05-27.

Z.K. Matthews quoted in G.V. Mqingwana, The Israelite movement and the Bulhoek episode (Unpublished MA thesis, Northwestern University, Evanston, Illinois, USA), p 84.

South African Studies 4, Nelson Mandela Speaks, p 42.

10 G.V.Mqingwana, The Israelite movement and the Bulhoek episode (Unpublished MA thesis, Northwestern University, Evanston, Illinois, USA), p 83.

See R.R. Edgar, Because they chose the plan of God: The story of the Bulhoek massacre. 


\section{THE INDUSTRIAL AND COMMERCIAL WORKERS UNION OF SOUTH AFRICA (ICU)}

Apart from the support received from the ANC, the Israelites also received tremendous support from the ICU. The Supreme Executive of the ICU passed a resolution stating "...that they wish to place on record their strongest protest against the unprovoked wholesale massacre of a defenceless and peaceful people at the instigation of the capitalist class, and also in pursuance of an autocratic policy propagated by the Union Government as indicated constantly in the confistication of native land, by which the natives may become destitute and thus by the use of force and military intimidation the workers may be reduced to economic slavery." ${ }^{2}$

To the ICU, the Israelites were not religious fanatics who came to Bulhoek to await the approaching end of the world prophecy taking place, but according to the Union they were workers who refused to work for the neighbouring white farmers. The Union further believed that the Israelites were the victims of the 1913 Land Act. This opinion was put forward by one of the Union leaders, Selby Msimang, who said: "Persuaded as I am by a deep conviction that if the land laws of this country were not as they are, and believing fully, as I do, that if Enoch Mgijima had ordered his proselytes to indenture their labour to the surrounding farmers of Kamastone or to give it gratis (free) in the name of his Church the killing and wounding of 400 natives would not have taken place... Man is not bound to confess loyalty to a tyrant. History has shown that the human soul naturally revolts against injustice."13

\section{THE COMMUNIST PARTY OF SOUTH AFRICA (CPSA)}

Another supporter of the Israelites was the CPSA. The most organized branch of the Communist Party of South Africa was in District Six, Cape Town. The branch convened a meeting at St. Mark's School in District Six on 30 May 1921 to protest against the Government's action at Bulhoek. During the meeting a resolution was adopted which condemned the Government's handling of the Israelites. The resolution stated that "the Bulhoek massacre was one of the most brutal things so far done by a Government which already had its hands steeped deep in the blood, not only of the natives at Port Elizabeth recently, but also of the workers at Johannesburg some years ago." 14

\section{THE GOVERNMENT'S REACTION}

The news of the Bulhoek massacre shocked the Union Government. There were diverse reactions to the incident. Following the news on the incident, General Smuts made a statement in Parliament. He stated that no one regretted what had happened more than the Government. He further outlined the various measures taken by the Government in dealing with the Israelites. He pointed out that the position had been made perfectly plain to the Israelites not only by General J.L. van Deventer (Union Defence Force), Colonel T.C. Truter (Commissioner of Police) and Mr E. Barrett (Secretary for Native Affairs), but also by the Native Affairs Commission. $\mathrm{He}$ referred to the protracted negotiations and the attitude of defiance taken by the Israelites. He felt that "...then came a time when nothing was left but to take action. The Government had nothing to do with religious movements, however wrong they might be, but the Government was going to see that the law is carried out and not defeated by any other movement... The instructions given to the police had been carried out to the letter."15

He continued and stated that "...the Government had done its best to avoid bloodshed, and makes it plain to the people, whether black or white, that they had to submit to obey the law of the land. The prevalent feeling is that the regrettable incident was unavoidable and that the law of the land must be enforced and it is also clear, from the whole history of the Israelite movement that the utmost leniency and forbearance have been displayed by the authorities at every stage of the proceedings. ${ }^{176}$

Following the Prime Minister's statement, various speakers in parliament criticised the Government for failing to avoid bloodshed at Bulhoek. In reply to the criticism the Prime Minister, said: "The instructions given were not to resort to violence and not to force bloodshed except in the very last resort, the ultimate resort, and I know that these instructions have been carried out to the letter. The Police reserved their fire until the very last moment. It was a case of so many hundreds of police well armed and so many thousands of poor, deluded natives, armed with such weapons as they had, but they came on and they seemed determined to swamp the police, and there was no alternative. I am persuaded in my own mind, and there seems to be no doubt in any guarder that there was no alternative for the police but to fire as they did. ${ }^{m 7}$

\footnotetext{
SAPS Archives: Box 4202, File 6/850/21 Press Cuttings, Rand Daily Mail, 1921-05-28.

13 State Library, Pretoria: Newspaper Collection; Cape Times, 1921-07-23; T. Karis and G. Carter, From protest to challenge, Vol 1, p 320.

14 State Library, Pretoria: Newspaper Collection; CapeTimes, 1921-05-31.

${ }_{15}$ State Library, Pretoria: Newspaper Collection; Cape Times, 1921-05-31

16 State Library, Pretoria: Newspaper Collection; Cape Times, 1921-05-26.

17. SAPS Archives: Box 4202, File 6/850/21/9 Miscellaneous, The Star, 1921-05-27
} 
While the Bulhoek issue was still being debated in parliament, General Smuts left the Union of South Africa for England. Mr F.S. Malan became the acting Prime Minister. Malan was questioned by General J.B.M. Hertzog then the leader of the National Party as to what the intentions of the Government regarding an inquiry into the Bulhoek affair were. Malan stated that the Government was awaiting reports to see whether there were any matters requiring further investigation. He stated further that if there were any matter requiring further investigation the Government would not object to a commission of enquiry. ${ }^{18} \mathrm{Mr} \mathrm{A}$. Barlow of the Labour Party criticised the Government for killing many people who had broken the smallest law of the country. He felt it should be part of the law that a judicial commission of enquiry ought to be appointed in every case where shooting took place. ${ }^{19}$ General Smuts on his return from England, replied that Barlow's statement was regrettable and that the few words he had spoken were more likely to ferment bad feeling between whites and blacks than any other. After receiving all the reports from the Police regarding operations at Bulhoek, the Government decided that there was nothing which needed further investigation and dropped the idea of appointing a commission of enquiry.

To prevent further debate and criticism on the incident the members of Parliament decided that the film Defiant Nature: Israelites at Bulhoek produced by $\mathrm{F}$. Ayliffe of African Film Productions Limited was to be banned. It was felt that it could be used as propaganda ammunition by the Government's critics. Mr Merriman said that if this film could not be destroyed it could do an incalcuble harm to the image of South Africa as it might be shown in England in connection with the League of Nations, as a sort of illustration of how a mandatory power treated its black population. ${ }^{20}$ The Government through the Commissioner of Police, Colonel T.C. Truter ordered African Films Productions Limited to hand all copies of the film to the Police to be destroyed. ${ }^{21}$

\section{THE NATIONAL PARTY, THE LABOUR PARTY AND THE ICU}

An unholy alliance developed between Africans, on the one hand, and the Afrikaner Nationalists and Labourites, on the other, which resulted from the Bulhoek incident. Although Hertzog, the leader of the Nationalist Party, had condemned the slaught- er and had called for a commission of enquiry into the matter he had done this not out of sympathy with Africans, but because of his abhorrence of the Smuts' Government. Realising that Africans were disgruntled with the Smuts' Government, the Nationalist and Labour Parties wooed them by pretending to sympathise with them so as to get their votes to oust Smuts. So deep was this fleeting alliance that Clements Kadalie, the National Secretary of the Industrial and Commercial Workers Union, invited Hertzog to a concert organised to raise funds for the survivors of the Bulhoek massacre. Hertzog did not attend, but expressed his sympathy for the bereaved and sent a donation to the Bulhoek Tragedy Fund as a token of his support. $^{22}$

Hertzog's letter to Kadalie (dated 21 July 1921), seen in the light of his party's policy and his subsequent legislation against Africans, proves that he was non-pareil as a political opportunist. Hertzog declared: "It is for us by our common endeavours to make this country that we love so much, great and good. In order to do that we must not only ourselves be good and great, but we must also see that there is established between white and black Afrikaner faith in and sympathy with one another which is so essential for the prosperity of the nation. It is my sincere desire that faith and sympathy shall exist, and to that end I hope to exert my influence."23

It was partly due to these political machinations which enabled Kadalie successfully to introduce a motion at the ANC conference in Bloemfontein, and at the Cape Native Voters Convention in King Williams's town in $1924,{ }^{24}$ calling for the support of the Nationalist-Labour Pact. As a result of this political miscalculation, among other factors, Hertzog defeated Smuts at the polls in 1924.

\section{THE INHABITANTS OF QUEENSTOWN AND THE GENERAL PUBLIC}

The inhabitants of Queenstown were greatly disturbed by the statements regarding the Bulhoek incident which had been made in Parliament. To them conclusions were made without regard to the facts. They felt that the Government and Police were being blamed for the wilful shooting of what the critics called "harmless Africans" for some "tri18 National Archives, Pretoria: Archives of the Minister of Native Affairs (hereafter NA), File 50/940 Israelites, Cape Times, 1921-06-
15.

19 National Archives, Pretoria: NA, File 50/940 Israelites, Cape Times, 1921-06-15.

20 National Archives, Pretoria: NA, File 50/929, Natives Miscellaneous, Might Do Incalcuble Harm, The Cape Argus, 1921-06-07

SAPS Archives: Box 4202, File 6/850/21/M, Bulhoek film, Letter, Colonel Truter, Commissioner of Police - Mr R.B. Coulthard,

General Manager, African Films Productions Limited, re: Film, Defiant Native Israelites at Bulhoek, 1921-06-04.

C. Kadalie, My life and the ICU, $\mathrm{p} 16$.

C. Kadalie, My life and the ICU, p 59.

C. Kadalie, My life and the ICU, pp 58-61. 
fling offence" and for not "treating the Israelites" with greater patience. ${ }^{25}$ An organisation which wanted to correct the misconceptions surrounding the Police action at Bulhoek, was the Vigilance Committee of Queenstown. It represented the townsmen and farmers in and around Queenstown. In trying to make its reaction to the Bulhoek incident known to the public, a public meeting was organised in Queenstown. During the meeting, various speakers pointed out that the people of Queenstown and district knew to what lengths the Government and Police had gone to in trying to avoid bloodshed at Bulhoek. The committee stated that the time had arrived that the country should be told that the deplorable loss of life was to be blamed on the Israelites themselves, and not on the Government or the Police. ${ }^{26}$

The meeting unanimously adopted two resolutions relating to the Israelites incident. The first resolution was directed at criticism passed in parliament and which had appeared in the press. The resolution stated that "In view of certain criticisms which have been passed in Parliament and have appeared in the press of the country in connection with the fighting which occurred at Bulhoek on May 24th last, this public meeting of residents of Queenstown and district, representing the people who have been most closely connected with the growing menace of the Israelite movement, resolves to place on record its appreciation for the firm action taken by the Government in the matter. Realising to the full the seriousness of the menace which the Israelites brought into our district, we were impatient and at times exasperated at the patience and forbearance of the Government authorities in dealing with the law breakers, and, while deploring the heavy casualties incurred in carrying out the law of the land, we are thankful that a sufficient force of Police was sent to prevent the possibility of an even greater calamity." ${ }^{27}$

The second resolution adopted during the meeting stated that "It resolves to place on record its high appreciation of the efforts of Colonel Truter, the officers and men under his command to bring the Israelites to a realisation of their position without resort to bloodshed. Every effort was made to induce the Prophet Enoch and his followers to allow the law to take its rightful course, and Colonel Truter showed most openly the power of the force which had been collected in Queenstown to administer the law. While his force was only 200 to 300 paces from the nearest armed body of Israelites a last effort was made to bring events to a peaceful end, but the reply was a mad charge by the Israelites on the police. Colonel Truter and his police are in no way responsible for the unavoidable bloodshed." 28

After passing these two resolutions supporting the policy of the Government at Bulhoek and exonerating the Police of blame for the bloodshed, a further resolution was passed asking the Government to deal leniently with the rank and file of the Israelites who were undoubtedly mislead by the Prophet Enoch and his assistants.

The Queenstown branch of the Sons of England and Benevolent Society, which represented over a hundred Englishmen in Queenstown and district joined the Vigilance Committee of Queenstown in upholding the Government's action at Bulhoek. The Society stated that "... it wished to place upon record its appreciation of the prolonged and exhaustive efforts of the authorities to find a peaceful solution to the problem." ${ }^{29}$ The Society further stated that "... while we deplore the loss of life entailed, we would like to express our conviction that the armed resistance to the forces of the Crown could have been dealt with in no other way, and testifies that the police resorted to force when there was no alternative whatever". ${ }^{30}$

The African population living at the various blocks of Kamastone location joined the two white societies of Queenstown in upholding the Government's action. Their negative attitude towards the Israelites were visible even months before the massacre. On the 4 September 1920, the headman of the various blocks of Kamastone location (Alfred Dondolo representing Bulhoek; George Maholwana, Zangqokwe; Alfred Mpaleni, Kamastone; Joseph Mayikiso, Didimana; Robson Matshoba, Romans Laagte; Mdunyelwa Mpulu, Mceula; Biko Sishuba, Hukuwa and Charles Bam, Upper Didima) organized a public meeting in Kamastone. ${ }^{31}$ During the meeting a letter was written to the Superintendent of Native Affairs at Kamastone, requesting him to act upon the Israelites as they had no permission to stay at Bulhoek. ${ }^{32}$ Following the massacre, a large

\footnotetext{
SAPS Archives: Box 4202, File 6/850/21/H, Newspaper Cuttings, Queenstown Daily Representative, 1921-06-02.

SAPS Archives: Box 4202, File 6/850/21/H, Newspaper cuttings, Queenstown Daily Representative, 1921-06-04.

SAPS Archives: Box 4202, File 6/850/21/H, Newspaper cuttings, Queenstown Daily Representative, 1921-06-04.

SAPS Archives: Box 4202, File 6/850/21/H, Newspaper Cuttings, Queenstown Daily Representative, 1921-06-04.

2 SAPS Archives: Box 4202, File 6/850/21/J; Commissioner's Report, LetterW.T. Whallery, President Queenstown branch of Sons of England and Benevolent Society - Secretary of Native Affairs, 1921-05-25.

30 SAPS Archives: Box 4202, File 6/850/21/J, Commissioner's Report, Letter W.T. Whallery, President Queenstown branch of the Sons of England and Benevolent Society - Secretary of Native Affairs, 1921-05-04.

31. National Archives, Pretoria: NA, File 420/13/387, Israelites Queenstown, Letter Headman of Kamastone - The Superintendent of Natives, Kamastone, 1920-09-04.

32 National Archives, Pretoria: NA, File 420/13/387, Israelites Queenstown, Letter Headman of Kamastone - The Superintendent of Natives Affairs, 1920-09-04.
} 
meeting of all the people of the various blocks of Kamastone was organized, during which chief headman Rofana Mblingi presided. During the meeting, the following resolution was unanimously carried. The resolution stated that "This meeting of over 300 Natives of Oxkraal and Kamastone locations, abutting Bulhoek, the Israelite camp, while regretting the loss of our brothers in the lamentable incident which took place on 24 May 1921, wish strongly to uphold the action which was reluctantly forced upon the Government, feeling that the Government did everything in it's power to avoid trouble and bloodshed; further, while not wishing to dictate to the Government, we would recommend the liberation of all the Israelite prisoners consisting of the rank and file, but that the most stringent punishment be meted out to the leaders to prevent a catastrophe of this nature taking place in the future." 33

Various individuals wrote letters to the newspapers expressing their opinions on the clash between the Israelites and the Police. A resident of Hukuwa, one of the blocks of Kamastone, wrote a letter to the Queenstown Daily Representative in which he heavily blamed the Israelites for the bloodshed at Bulhoek. In the letter he stated: "I wish it to be known by both white and black in the whole of South Africa that the Government is innocent of the blood that flowed at Bulhoek on the 24th of May, 1921. The only people who are responsible are the Israelites themselves. Much as it is sad and painful, the blame should not be put at the wrong side. Since 17 December 1920 I have followed the efforts of the Government, and in fact, I have myself done my best. The patience with which the Government dealt with this matter is unprecedented, as far as history is concerned." ${ }^{34}$

In another letter, S.H. Mbulawa, of Longlands, Barkly West, stated that the Israelites were misled and misguided by a religious madman. ${ }^{35}$ The Government's action was appreciated by another African, Aaron Alfred Toba, of Ndabeni location in Cape Town. In a letter to the editor of Cape Argus he stated: "There is no getting away from the fact that the patience shown by the authorities concerned to the Israelites, who time and time again defied the law and order, in spite of repeated warnings was most commendable." ${ }^{36}$

African intellectuals of the time did not hesitate to criticize the Israelites after the incident. D.D.T Jabavu, a lecturer at Fort Hare College, argued that education rather than primitive religion should be the proper channel for preparing Africans for leadership positions. He saw Enoch Mgijima as an example of an untrained intellect with an undisciplined mind that could have been changed by institutions such as Fort Hare. D.D.T Jabavu's father, John Tengo Jabavu, who was the editor of Imvo Zabantsundu, criticised the Israelites more harshly than his son. To him the Israelites was as much a political movement as a religious one. The main purpose of the movement he urged was to challenge the laws and practices of the Union Government. In voicing his attitudes towards the Israelites he said: "That the people were demented there remains no room for doubt; and no enquiry however searching, can reveal anything... Some, with wisdom after the event say that the Government should have dealt drastically with the movement from the start... At the bottom it is a political movement identified with worship. The main object being to drive the white man from the country. The prevailing unrest comes from the same cause. Where an Israelite is or any semi-religious movement exists we have sermons from the same text and if Government were wise it would closely watch movement with this root of bitterness before it becomes prosperous as Mgijima's at Ntabelanga." ${ }^{37}$

Although the Transkeian General Council was horrified by the massacre, it did not sympathise with the Israelites. In a telegram sent to the Native Affairs Department, the Council stated: "That this Council has heard with regret of the bloodshed which occurred during the dispersal of the Israelites in Queenstown, which appears to have been unavoidable, and while recognising that Government must be firm with these fanatics, begs that justice will be softened by mercy as far as it is possible without risk to the country." ${ }^{18}$

\section{THE VARIOUS NEWSPAPERS}

There were also diverse reactions in the various newspapers. Following the massacre, almost all the newspapers carried reports on the incident. Umteteleli wa Bantu, published in Johannesburg at the time and which was directed towards the African population, carried an article entitled "The Slaying" in which the action of the Government was appreciated. It stated: "Every reasonable Native will admit that the religious maniacs at Bulhoek brought punishment upon themselves, and will share our appreciative recognition of the great patience displayed by the Government. In the hope that Enoch and his dupes would hear reason and yield to the law, the Government's official representatives have

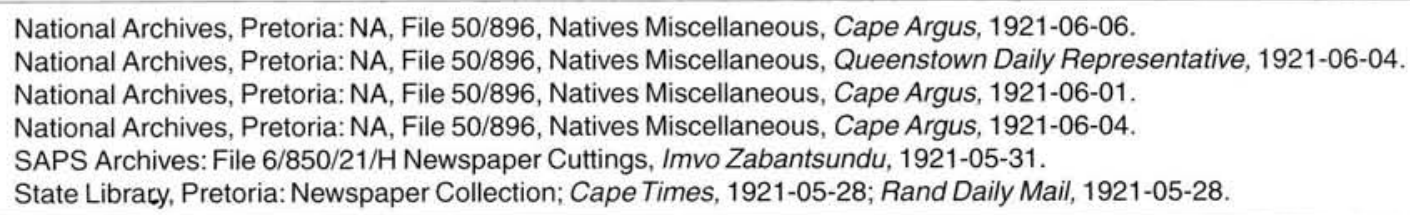


on several occasions visited the Israelites camp and have endeavoured to convince them that of their wrong doings. It ultimately became clear to every one that the unfortunate people were reduced to a state of absolute unreason, and that they were madmen in fact. The Government found itself compelled at last to adopt sterner measures, and the overwhelming force of police which was collected was doubtlessly justified by the obvious fanaticism of the Natives and all that it might mean in blind fury; and it was a possible factor for mercy. Whether or not the Israelites might have been overcome without so much loss of lives, and whether or not the police programme was faulty we cannot discuss; but we deplore the issue of the affair, and we mourn that so many human lifes were thrown away in the pursuit of a wild religious fancy. The episode will, we trust, serve as a warning to those natives who take religion badly, and who are greater devotees of the mysticism than of the plain elements of christianity." 39

Another African paper which did not sympathise with the Israelites was the Imvo Zabantsundu. Its editor, John Tengo Jabavu, spoke harshly on the Israelites as was previously mentioned. The paper attacked the behaviour of the Israelites when they refused to appear in court in East London as witnesses for the Crown in the case in which the farmer, Mattushek was charged for shooting an African. On this issue the paper said: "The patience and the indulgence of the Government in regard to these people has everything to commend it, especially as the charges aimed at them were cloudy; but a deliberate disregard of the higher Courts or any Court can not be tolerated; and we earnestly trust no further trouble will be incurred in connection with the execution of the Judge's warrant in arresting the witnesses". ${ }^{40}$

In an editorial comment on the massacre Imvo Zabantsundu stated that "...It mattered not to them (Israelites) whether 'the prophet' was a true or a false prophet. They were listening and believing 'his prophecies' and ignored the laws of those placed in authority over them by 'Jehovah'.... Force was threatened, But while saying so they were busy sharpening their swords and assegais against the Government....Meantime a strong Government force appeared on the scene with instructions not to shoot unless in self-defence. The Israelites on their side marshalled their tin-pot army and stated they would fight - not Jehovah this time. In spite of all efforts to get them to surrender they sacrificed themselves against cold steel in the false belief that the guns, after the Nxele 'prophecy' in the 1850 war with the Natives.... It was not until seeing this carnage that the prophet and his advisers observed that 'Jehovah' as of old, was on the side of battalions; and surrendered himself and his followers. That the people at Bulhoek were demented; and no inquiry, however searching can reveal anything. The whole history of the matter has been enacted by an open diplomacy on both sides and cannot be glossed over... Some with wisdom after the event, say that the Government should have dealt drastically with the movement at the start. We believe that they mean when Msikinya brought the sect from America. At the bottom it is a political movement identified with worship. The main object being to drive the white man from the country. We fear it is not the only movement of the kind in the country. The prevailing unrest comes from the same cause. Where an 'Israelite' is or any semireligious movement exists we have sermons from the same text and if Government were wise they would closely watch movements with this root of bitterness before it becomes prosperous as Mgijima's at Ntabelanga." 41

The Star, regarded the Israelites as "deluded people", and took a strong stand against the Government. It pointed out that the Government's refusal to appoint a commission of enquiry might cause considerable concern in view of the racial complexity of the South African situation. ${ }^{42}$ The Pretoria News attacked the South African Native Congress for criticising the Government and putting forward suggestions on how the Government could have dealt with the Israelites only after the massacre had taken place. To the Pretoria News the Israelites were religious fanatics who refused to allow the authorities even to take action with regard to sanitation so that they could be safeguarded against an epidemic. ${ }^{43}$

A more penetrating comment came from Die Burger of 16 June 1921 which "...expressed the fear that the Natives might come to view the Bulhoek massacre in the same light as the Afrikaners viewed the Slaghter's Nek Rebellion." ${ }^{44}$ The Slaghter's Nek Rebellion is one of the emotional issues amongst the Afrikaners, and in Afrikaner nationalistic historiography. The significance of this observation as Mqingwana argued did not lie in the fact that it had the historical perspicacity to draw the analogy, but

\footnotetext{
National Archives, Pretoria: NA, File 50/896, Natives Miscellaneous, Umteteleli Wa Bantu, 1921-05-28.

National Archives, Pretoria: NA, File 50/896, Natives Miscellaneous, Imvo Zabantsundu, 1921-05-19.

State Library, Pretoria: Newspaper Collection; Imvo Zabantsundu, 1921-05-31, p 5

State Library, Pretoria: Newspaper Collection; The Star, 1921-05-29.

State Library, Pretoria: Newspaper Collection; Pretoria News, 1921-05-27.

W.K. Hancock, Smuts: The Fields of Force, 1919-1950, p 98. For details on Slaghter's Nek Rebellion in Afrikaans nationalistic historiography see F.A. van Jaarsveld, The awakening of Afrikaner Nationalism, pp 162-3, 200, 224.
} 
because it was a newspaper that championed Afrikaner nationalistic interests. ${ }^{45}$

\section{CONCLUSION}

What emerged from debates on the Bulhoek massacre is that various political organisations, members of parliament, people who lived in the vicinity of Queenstown, the public at large and the various newspapers, have different perspectives on the massacre. Some base their arguments on facts while others responded in line with their organisational ideology. This is clearly illustrated by the response from various political organisations such as SANNC, SACP, ICU. The ANC continued to view it as part of the African struggle for national liberation. Others such as the people who lived in the vicinity of Bulhoek, the Union Government and various newspapers continued believing that the outcome was to be blamed on Enoch Mgijima. The change in the Government of South Africa, the empowerment of the ANC and the new approach towards South Africa's history might add a new dimension to the Bulhoek massacre. It is hoped that future researchers will study the facts and interpret them and not conform the outcome of their research to suit an ideology as was the case with the Bulhoek massacre in the 1980's.

\section{BIBLIOGRAPHY}

\section{PRIMARY SOURCES \\ NATIONAL ARCHIVES, PRETORIA}

\section{ARCHIVES OF THE MINISTER OF NATIVE AFFAIRS}

NA: File 420/13/387 Israelites Queenstown

NA: File 50/896 Natives Miscellaneous
NA: File 50/929 Natives Miscellaneous

NA: File 50/940 Israelites

\section{SOUTH AFRICAN POLICE SERVICE ARCHIVES, PRETORIA}

Box 4202, Bulhoek massacre records:

File 6/850/21, Press Cuttings

File 6/850/21/9, Miscellaneous

File $6 / 850 / 21 / \mathrm{H}$, Newspaper Cuttings

File 6/850/21/J, Commissioner's Report

File $6 / 850 / 21 / \mathrm{M}$, Bulhoek film

\section{SECONDARY SOURCES}

\section{STATE LIBRARY, PRETORIA: NEWSPAPER COLLEC- TION}

Cape Times, 1921-05-26, 1921-05-28, 1921-05-31 and 1921-07-23.

Imvo Zabantsundu, 1921-05-31.

Pretoria News, 1921-05-27.

Meeting of the South African Native Congress. Rand Daily Mail, 1921-05-28.

Native Congress Resolutions. The Star, 1921-05-29.

MAKOBE, D.H., Confrontation with the Police:The Israelites of Enoch Mgijima and the Bulhoek massacre of 24 May 1921. Militaria 26(1), 1996.

EDGAR, R.R., Because they chose the plan of God: The story of the Bulhoek massacre. Johannesburg, 1988.

HANCOCK, W.K., Smuts: The Fields of Force, 1919-1950. Cambridge, 1968.

KADALIE, C., My life and the ICU. London, 1970.

KARIS, T. and G. CARTER, From Protest to challenge, Vol 1. Stranford, 1972.

MQINGWANA, G.V., The Israelite movement and the Bulhoek episode. Unpublished MA thesis, Northwestern University, Evanston, Illinois, USA, June 1976.

South African Studies 4, Nelson Mandela Speaks, London, nd. VAN JAARSVELD, F.A., The awakening of Afrikaner Nationalism. Cape Town, 1961. 